\title{
Ultrasound-guided infraclavicular and sciatic block for a patient who had surgery simultaneously for sindactili of the right hand and polydactilia of the right foot: Case report
}

\author{
Eş zamanl olarak să̆ elinden sindaktili ve să̆ ayă̆ından \\ polidaktili için operasyon geçiren hastada ultrason rebberliğinde \\ infraklavikular ve siyatik blok: Olgu sunumu
}

Yavuz GÜRKAN, Can AKSU, Kamil TOKER, Mine SOLAK

\begin{abstract}
s
Summary

A major advantage of ultrasound (US) has been reduction in the amount of local anaesthetic (LA) needed for successful blocks. Reduced LA requirement reduces the risk of LA toxicity when multiple blocks are to be done for surgery of more than one extremity in the same patient. The 38-year-old female was scheduled for elective surgery of polydactilia in her right foot and syndactili in her right hand. A sciatic nerve block and an infraclavicular block were applied to the patient, with ultrasound guidance. The sciatic block was performed at the popliteal level in figure of four position in prone position. The lateral sagital technique was used for the infraclavicular block. Both blocks were successful, and the patient was ready for surgery 30 minutes after block performances. The patient didn't need any additional anaesthetic or analgesic during the operation. Surgery was performed uneventfully on both extremities. This is the first case report in the literature in which multiple blocks were applied to two different extremities, the leg and arm. In conclusion, our case report is a good example of multiple blocks in different extremities being performed successfully and safely according to US guidance and using low doses of local anaesthetics.
\end{abstract}

Key words: Infraclavicular block; multiple peripheral nerve blocks; sciatic block; ultrasound.

\section{Özet}

Ultrasonun (US) büyük avantajlarından birisi başarılı blok için gereken lokal anestetik (LA) miktarındaki azalmadır. Azalmış LA gereksinimi, birden fazla ekstremitesinden ameliyat olacak bastaya çoklu blok yapilırken LA toksisitesi riskini azaltır. Otuz sekiz yaşında kadın hasta, să̆ ayağında polidaktili, sağ elinde sindaktili için elektif ameliyatı planlanmış. Siyatik sinir bloğu ve infraklavikular blok, hastaya, US rebberliğinde yapildı. Siyatik blok, pron, "figure of four" pozisyonunda, popliteal seviyede uyguland. Infraklavikular blok için lateral sagital teknik kullanild. İki blok da başarılı oldu ve hasta blok uygulamalarından 30 dakika sonra operasyona hazıdd. Operasyon süresince hastanın herbangi bir ek anestetik ve analjezik ibtiyact olmadi. Operasyon her iki ekstremitede sorunsuz olarak gerçekleştirildi. Bu, literatürdeki, kol ve bacak olarak, iki farkl ekstremitede çoklu blok uygulanan ilk olgu sunumudur. Sonuç olarak bizim olgu sunumumuz, farkl ekstremitelerde çoklu blokların, US rehberliğinde düşük doz LA kullanılarak, başaril ve güvenli bir şekilde uygulanabildiğini gösteren güzel bir örnektir.

Anahtar Kelimeler: İnfraklavikular blok; çoklu periferik sinir bloğu; siyatik blok; ultrason.

\section{Introduction}

Ultrasound (US) guidance during nerve blocks has provided a revolutionary improvement during re- gional anesthesia practices due to improved block success rate and patient safety. One of the major advantages of US has been reduction in local anes-

Department of Anesthesia and Reanimation, Kocaeli University Faculty of Medicine, Kocaeli, Turkey Kocaeli Üniversitesi Tıp Fakültesi, Anesteziyoloji ve Reanimasyon Anabilim Dalı, Kocaeli

Submitted (Başvuru tarihi) 10.10.2011 Accepted after revision (Düzeltme sonrası kabul tarihi) 26.12.2012

Correspondence (İletişim): Dr. Can Aksu. Kocaeli Üniversitesi Tıp Fakültesi Hastanesi, Anesteziyoloji ve Reanimasyon Anabilim Dalı, 2 Nolu Ameliyathane, Umuttepe, İzmit, Kocaeli, Turkey. Tel: +90 - 262 - 3038248 e-mail (e-posta):dr.aksu@gmail.com 
thetic (LA) amount needed for successful blocks. ${ }^{[1-3]}$ Reduced LA requirement reduces the risk of LA toxicity when multiple blocks are to be done for surgery of more than one extremity in the same patient.

\section{Case Report}

We present a case of a 38-year-old female patient, $163 \mathrm{~cm}$. tall and who weighs $60 \mathrm{~kg}$, ASA physical status I, who had congenital polydactilia and syndactili. The patient was scheduled for elective surgery of polydactilia at her right foot and syndactili at her right hand. There was no contraindication for general anesthesia but we thought that these two surgical procedures could done with the regional techniques so that prolonged postoperative analgesia could also be provided.

On arrival to the pre-anesthesia holding area where blocks were performed, standard monitoring was applied (electrocardiogram, pulse oximetry and noninvasive blood pressure) and an intravenous catheter was placed in the left forearm of the patient. ${ }^{[4]}$ The patient had an infusion of $0.9 \%$ isotonic started IV before block performance. Sedation was provided with intravenous midazolam $2 \mathrm{mg}$. For the sciatic nerve block, the patient was positioned in "figure of four" in prone position. ${ }^{[5]}$ After disinfection and sterile draping of the probe, sterile gel was applied to the procedure area. A linear $10-18 \mathrm{MHz}$ US transducer (Esaote Mylab30, Florence, Italy) was placed transverse plane to popliteal fossa. At the popliteal crease the tibial nerve was seen as hyperechoic structure. After the tibial and peroneal nerves were identified, transducer was moved proximally until the sciatic nerve was seen where the tibial and peroneal nerves were bifurcated. Then we have progressed proximally $2 \mathrm{~cm}$ more. A 22 gauge $80 \mathrm{~mm}$ needle (Pajunk, Melsungen, Germany) was inserted under the probe's long axis (in plane technique). LA mixture of $10 \mathrm{ml}$ of levobupivacaine $0.5 \%$, and 10 $\mathrm{ml}$ of lidocaine $2 \%$ (total volume $20 \mathrm{ml}$ ) was administered to achieve circumferential spread of LA around the sciatic nerve.

After the sciatic nerve block the patient turned to supine position for infraclavicular block. Lateral sagital infraclavicular technique was used for infra- clavicular block. ${ }^{[6]}$ The arm to be blocked was adducted and the hand was on the abdomen. The head was rotated slightly to the opposite direction. The point where the clavicle meets the coracoid process was palpated. The puncture site was immediately adjacent to the most medial point of the coracoid process and the anterior surface of the clavicula. After antiseptic preparation of the area with povidone iodine the same linear $10-18 \mathrm{MHz}$ US transducer was placed. The axillary artery was then imaged in the sagittal plane. 22G $80 \mathrm{~mm}$ needle (Pajunk Needle, Germany) was inserted using in-plane technique. LA mixture of $10 \mathrm{ml}$ of levobupivacaine $0.5 \%, 10 \mathrm{ml}$ of lidocaine $2 \%$ (total volume $20 \mathrm{ml}$ ) was administered. The LA was injected as to form ' $U$ " like distribution around the axillary artery and the cords.

Throughout all needle insertions and re-directions, continuous aspiration of the syringe was performed by an assistant to detect any possible intravascular puncture.

Both blocks were successful and the patient was ready for surgery 30 minutes after block performanc-

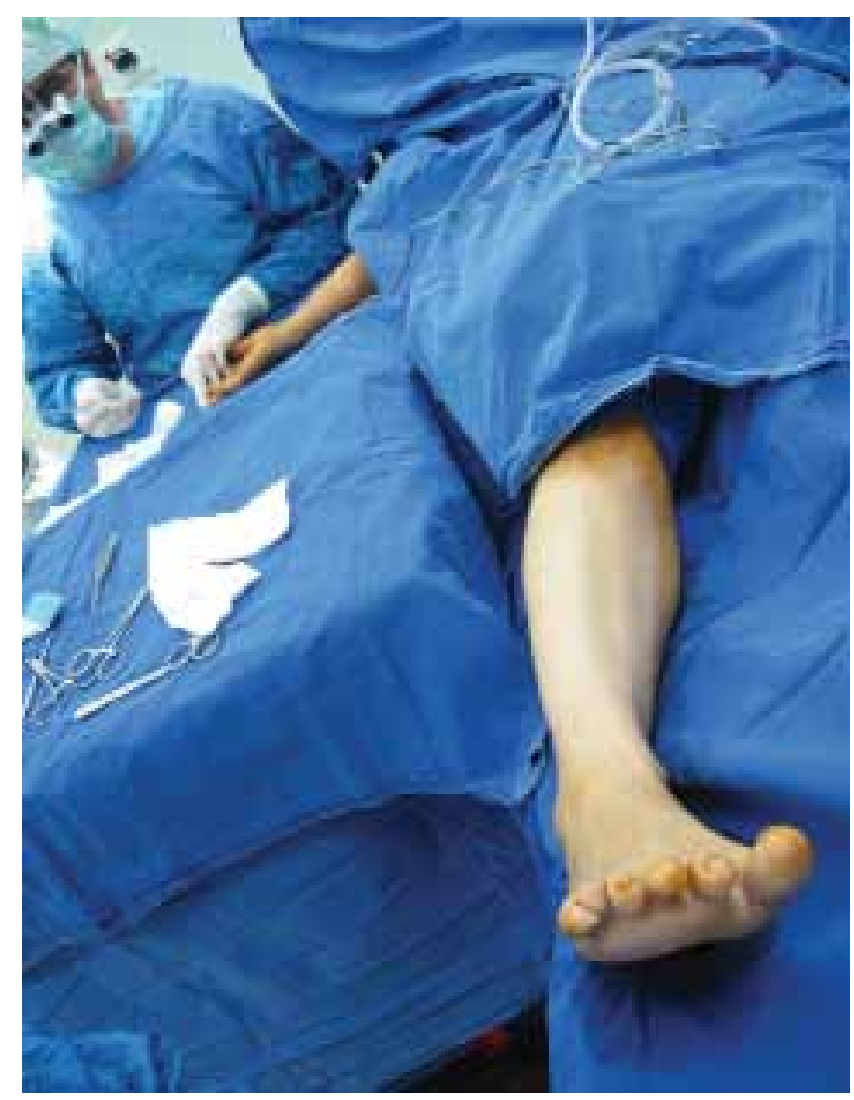

Figure 1. Two surgical teams operated on both extremities simultaneously. 
es. Two surgical teams operated on both extremities simultaneously (Figure 1). Operation lasted for 2.5 hours. The patient did not need any additional anesthetic or analgesic during the operation. Surgery was performed uneventfully on both extremities. 1 st, 6th, 12th and 24th hour VAS scores were below 3. First additional analgesic was given 27 hours after the surgery. The patient has been discharged from the hospital on second day of the operation.

\section{Discussion}

There are few reports on multiple nerve blocks in the literature. ${ }^{[7,8]}$ Multiple blocks carry the risk for systemic LA toxicity. A large dose and volume of anesthetic has been one of the important determinants of successful block using conventional methods. $40 \mathrm{ml}$ of local anesthetic mixture is needed for infraclavicular block whilst $25 \mathrm{ml}$ of local anesthetic is needed for sciatic nerve block. ${ }^{[9]}$ US guidance allowed reduced LA doses without compromising success rate of the blocks. Latzke et al. ${ }^{[2]}$ reported that the ED99 value of LA volume for sciatic nerve block is $0.1 \mathrm{ml} / \mathrm{mm}^{2}$ cross sectional nerve area. They further reported the mean value for sciatic nerve area as $57 \mathrm{~mm}^{2}$. Eichenberger et al. ${ }^{[3]}$ reported that ED95 value of LA volume for ulnar nerve block is $0.11 \mathrm{ml} / \mathrm{mm}^{2}$ cross sectional nerve area. ${ }^{[2]}$ They reported that the mean cross-sectional area of the ulnar nerve was $6.2 \mathrm{~mm}^{2}$. O'Donnell et al. ${ }^{[10]}$ reported successful axillary block using only one milliliter of $2 \%$ lidocaine per nerve. Although the volumes in these articles are lower than our experience they are a little bit far from practice. But findings of these research articles encourage multiple blocks to be performed without the risk of LA toxicity.

Sandhu et al. ${ }^{[7]}$ using US guidance reported simultaneous bilateral infraclavicular brachial plexus block with total amount of $40 \mathrm{ml} 2 \%$ lidocaine. In a similar way Tekin et al. ${ }^{[8]}$ reported bilateral infraclavicular block with total amount of $40 \mathrm{ml}$ LA mixture of $2 \%$ lidocaine and $7.5 \%$ levobupivacaine using US guidance while Maurer et al11 reported bilateral infraclavicular block with $70 \mathrm{ml}$ of ropivacaine $\% 0.5$. Çiftçioğlu et al. reported bilateral popliteal block with right femoral nerve block in a high risk patient. ${ }^{[12]}$

Until now all of the multiple block cases in literature have been described for the upper extremities. This is the first case report in the literature that multiple blocks had been done in two different extremities, as the leg and the arm.

In conclusion, our case report is a good example that multiple blocks in different extremities can be performed successfully and safely by US guidance using low doses of local anesthetics.

\section{Conflict-of-interest issues regarding the author- ship or article: None declared.}

\section{Peer-rewiew: Externally peer-reviewed.}

\section{References}

1. Marhofer $\mathrm{P}$, Schrögendorfer $\mathrm{K}$, Wallner T, Koinig H, Mayer $\mathrm{N}$, Kapral S. Ultrasonographic guidance reduces the amount of local anesthetic for 3-in-1 blocks. Reg Anesth Pain Med 1998;23(6):584-8. CrossRef

2. Latzke $D$, Marhofer $P$, Zeitlinger $M$, Machata $A$, Neumann $F$, Lackner $E$, et al. Minimal local anaesthetic volumes for sciatic nerve block: evaluation of ED 99 in volunteers. $\mathrm{Br} J$ Anaesth 2010;104(2):239-44. CrossRef

3. Eichenberger U, Stöckli S, Marhofer P, Huber G, Willimann P, Kettner SC, et al. Minimal local anesthetic volume for peripheral nerve block: a new ultrasound-guided, nerve dimension-based method. Reg Anesth Pain Med 2009;34(3):242-6.

4. Gürkan Y, Ozdamar D, Hoşten T, Solak M, Toker K. Ultrasound guided lateral sagital infraclavicular block for pectoral flap release. Agri 2009;21(1):39-42.

5. Gürkan Y, Sarisoy HT, Cağlayan C, Solak M, Toker K. "Figure of four" position improves the visibility of the sciatic nerve in the popliteal fossa. Agri 2009;21(4):149-54.

6. Klaastad $\varnothing$, Smith HJ, Smedby O, Winther-Larssen EH, Brodal $\mathrm{P}, \mathrm{Breivik} \mathrm{H}$, et al. A novel infraclavicular brachial plexus block: the lateral and sagittal technique, developed by magnetic resonance imaging studies. Anesth Analg 2004;98(1):252-6.

7. Sandhu NS, Maharlouei B, Patel B, Erkulwater E, Medabalmi P. Simultaneous bilateral infraclavicular brachial plexus blocks with low-dose lidocaine using ultrasound guidance. Anesthesiology 2006;104(1):199-201. CrossRef

8. Tekin M, Gürkan Y, Ceylan DB, Solak M, Toker K. Ultrasoundguided bilateral infraclavicular block: case report. Agri 2010 Jan;22(1):41-3.

9. Hadzic A. Textbook of regional anesthesia and acute pain menagement. In: Clinical practice of regional anesthesia, Infraclavicular brachial plexus block. New York: McGrawHill; 2006. p. 427-41; Sciatic nerve block. p. 517-33.

10. O'Donnell B, Riordan J, Ahmad I, lohom G. Brief reports: a clinical evaluation of block characteristics using one milliliter $2 \%$ lidocaine in ultrasound-guided axillary brachial plexus block. Anesth Analg 2010;111(3):808-10. CrossRef

11. Maurer K, Ekatodramis G, Rentsch K, Borgeat A. Interscalene and infraclavicular block for bilateral distal radius fracture. Anesth Analg 2002;94(2):450-2. CrossRef

12. Çiftçioğlu $M$, Acar $S$, Gürkan $Y$, Solak $M$, Toker K. Ultrasound guided multiple peripheral nerve blocks in a high-risk patient. Agri 2012;24(2):90-2. CrossRef 